\title{
Identification of a novel population of human cord blood cells with hema- topoietic and chondrocytic potential
}

\author{
Karen E JAY ${ }^{1,2}$, Anne ROULEAU ${ }^{1}$, T Michael UNDERHILL ${ }^{3}$, Mickie BHATIA ${ }^{1,2,3, *}$ \\ ${ }^{1}$ Stem Cell Biology and Regenerative Medicine, The John P. Robarts Research Institute, 100 Perth Drive, London, Ontario, \\ N6A $5 K 8$, Canada. \\ ${ }^{2}$ Department of Microbiology and Immunology, The University of Western Ontario, London, Ontario, Canada. \\ ${ }^{3}$ Department of Physiology, The University of Western Ontario, London, Ontario, Canada.
}

\begin{abstract}
With the exception of mature erythrocytes, cells within the human hematopoietic system are characterized by the cell surface expression of the pan-leukocyte receptor CD45. Here, we identify a novel subset among mononuclear cord blood cells depleted of lineage commitment markers ( $\mathrm{Lin}^{-}$) that are devoid of CD45 expression. Surprisingly, functional examination of Lin ${ }^{-}$D $45^{-}$cells also lacking cell surface CD34 revealed they were capable of multipotential hematopoietic progenitor capacity. Co-culture with mouse embryonic limb bud cells demonstrated that Lin $^{-} \mathrm{CD}^{-} 5^{-} \mathrm{CD}^{-} 4^{-}$cells were capable of contributing to cartilage nodules and differentiating into human chondrocytes. BMP-4, a mesodermal factor known to promote chondrogenesis, significantly augmented Lin ${ }^{-}{ }^{-4} 5^{-} \mathrm{CD}^{-} 4^{-}$differentiation into chondrocytes. Moreover, unlike $\mathrm{CD}^{+} 4^{+}$human hematopoietic stem cells, Lin ${ }^{-} \mathrm{CD} 45^{-} \mathrm{CD} 34^{-}$cells were unable to proliferate or survive in liquid cultures, whereas single Lin ${ }^{-} \mathrm{CD} 45^{-} \mathrm{CD} 34^{-}$cells were able to chimerize the inner cell mass (ICM) of murine blastocysts and proliferate in this embryonic environment. Our study identifies a novel population of $\mathrm{Lin}^{-} \mathrm{CD}^{-} 5^{-} \mathrm{CD} 34^{-}$ cells capable of commitment into both hematopoietic and chondrocytic lineages, suggesting that human cord blood may provide a more ubiquitous source of tissue with broader developmental potential than previously appreciated.
\end{abstract}

Keywords: hematopoietic, chondrocyte, CD45, embryonic.

\section{INTRODUCTION}

Human hematopoietic stem cells (HSCs) have been identified in bone marrow (BM), peripheral blood and umbilical cord blood (CB) [1-4]. Initially, the functional capacity of the cells derived from these tissues was believed to be restricted to a hematopoietic cell fate. This view changed, however, when marrow-derived stromal cells were found to differentiate along the osteogenic lineage [5-7]. These new findings prompted further analysis of cells comprising the BM compartment, revealing that multipotent mesenchymal stem cells (MSCs) reside within the BM, and were capable of giving rise to adipose, bone, cartilage, skeletal muscle and endothelial cell lineages [8, 9]. These combined findings have led to the current notion

\footnotetext{
${ }^{*}$ Correspondence: Mickie BHATIA

Tel: (519) 663-5777 Ext. 34166; Fax: (519) 663-2982;

E-mail: mbhatia@robarts.ca
}

Abbreviations: Agc, Aggrecan; BM, Bone marrow; CB, Cord blood; HSC, Hematopoietic stem cell; ICM, Inner cell mass; MSC, Mesenchymal stem cell; BMP, Bone Morphogenetic Protein. that BM is therefore a source of both MSCs as well as HSCs. Similar to BM, human HSCs can also be found in umbilical CB and peripheral blood [2-4], however, studies aimed at isolating mesenchymal cells from these alternative hematopoietic sources have provided mixed results. Cells from pre-term CB displayed mesenchymal properties [10] while more recent studies reported a lack of MSCs from full term CB $[11,12]$. Similarly, contradicting reports have demonstrated the presence or absence of mesenchymal precursors from peripheral blood [12, 13].

Human CB contains a combination of primitive cells and mature cells that have committed to the various hematopoietic lineages $[14,15]$. Previous investigations have focused on the characterization and clinical utility of stem cells from CB partly due to the ease of obtaining this abundant cell source and the decreased immunogenicity of these cells upon allogenic transplantation [16, 17]. For hematopoietic cell fate, progenitors capable of multi-lineage hematopoiesis reside among cellular subsets of uncommitted $\mathrm{CB}$ cells that do not express specific hematopoietic lineage markers. These mature CB cells can be removed based 
on the surface expression of proteins associated with various hematopoietic lineages to derive a remaining subset of primitive cells referred to as the lineage depleted ( $\left.\mathrm{Lin}^{-}\right)$ fraction [18]. Candidate human HSCs have been shown to exclusively reside in the Lin $^{-}$fraction and can be further enriched to Lin $^{-}$subsets expressing CD34 but devoid of CD38 (Lin-CD34 ${ }^{+}$CD38-) [18]. Subsequent studies identi-

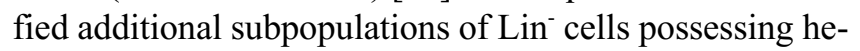
matopoietic progenitor function that was devoid of both CD34 and CD38 (Lin ${ }^{-C D} 34^{-}{ }^{-C D} 38^{-}$), indicating that CD34 may not be unique to the human HSC phenotype [19-23]. This series of studies illustrates the heterogeneity of the Lin ${ }^{-C D} 34^{-}$population in human $\mathrm{CB}$ and suggests that additional subpopulations may remain to be identified within the Lin $^{-}$population.

Here, we identify a novel population of cells in human CB devoid of the hematopoietic cell fate marker, CD45. Functional analysis of the $\mathrm{Lin}^{-} \mathrm{CD} 45^{-} \mathrm{CD} 34^{-}$cells revealed that similar to $\mathrm{CD}^{4} 5^{-} \mathrm{CD} 34^{-}$cells from BM $[8,9]$, these cells possess chondrocytic differentiation potential and hence share properties of mesenchymal progenitors. However, unlike BM-derived mesenchymal stem cells, CB

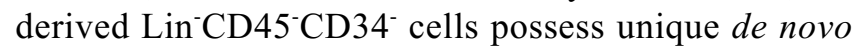
multi-lineage hematopoietic progenitor capacity. Lin-CD45 CD34- cells could not be propagated or maintained in conditions optimized for candidate HSC or MSCs. Using murine blastocysts to recapitulate an embryonic environment, Lin-CD45-CD34- cells displayed the ability to integrate into the ICM and underwent cell division. The functional potential displayed by this novel population suggests that Lin ${ }^{-} \mathrm{CD} 45^{-} \mathrm{CD} 34^{-}$cells derived from human $\mathrm{CB}$ are potential therapeutic targets for cellular therapies for osteogenic as well as hematopoietic deficiencies and represent a population of human cells with unique developmental potential.

\section{MATERIALS AND METHODS}

\section{Human and mouse mononuclear cell isolation and purifica- tion of primitive cell populations}

Samples of full term human umbilical cord blood (CB) were obtained in conjunction with local ethical and biohazard authorities of the University of Western Ontario and London Health Sciences Centre. Mononuclear cells were collected by separation in Ficoll-paque (Pharmacia, Piscataway, NJ) as shown previously [18]. Lineage depleted ( Lin $\left.^{-}\right)$cells were purified [18] and were stained with CD45 fluorescein isothiocyanate (FITC), CD34-allophycocyanate (APC) and CD38-peridinin chlorophyll protein-cyanin 5.5 (PCy5) monoclonal antibodies, and subsets isolated on a Vantage $\mathrm{SE}^{\mathrm{TM}}$ (Becton Dickinson). Bone marrow cells from EGFP transgenic mice (GFP/ FVB[TgN(ubEGFP)6752Dag]), generous gift from Dr. D Gray (University of Ottawa) were isolated by flushing the extracted tibia, femur, and iliac crest bones. Enrichment of undifferentiated primitive cells was carried out as previously described [24] and Sca-1 positive cells were isolated by cell sorting after staining with Sca-1phycoerythrin (PE) (Becton Dickinson).

\section{Membrane labeling of purified human and mouse subpopu- lations}

Purified fractions were washed after cell sorting and 10,000-20, 000 cells in $200 \mu 1$ volumes were labeled with $4 \times 10^{-6} \mathrm{M}$ PKH-26 dye (Sigma-Aldrich) for $5 \mathrm{~min}$ at room temperature. Fetal bovine serum was added to stop the reaction and cells were washed 3 times with PBS.

\section{Embryonic mouse limb bud cultures}

Cultures were prepared from murine fore and hind limb buds of E11.25-E11.75 embryos (obtained from time-pregnant CD-1 femalesas previously described) [25]. Cells were digested with Dispase (GIBCO BRL) and filtered through a Cell Strainer ( $40 \mu \mathrm{m}$, Falcon) to obtain a single cell suspension. Mouse cells and human-mouse cocultures were cultured in tissue culture plastic (Nunc) or glass chamber slides (Falcon). Culture media (40\% Dubelcco's Modified Eagle's Medium and $60 \%$ F12 supplemented with fetal bovine serum to $10 \%$, GIBCO BRL) was changed daily. BMP-4 (R and D Systems) was added to culture media to concentration of $10 \mathrm{ng} / \mathrm{ml}$. D 1 was considered to begin $24 \mathrm{~h}$ after initiation of culture. Labeled purified human subpopulations at 500 cells $/ 10 \mu 1$ were mixed with limb bud cells and plated. For each subpopulation, cells from 3 independent CB samples were divided into 12 wells for co-culture treatment. After $3 \mathrm{~d}$, cells were washed and fixed with $4 \%$ paraformaldehyde followed by alcian blue staining for detection of cartilage nodules [26] and covered with plastic coverslips if needed. Visualization and collection of images was accomplished using a Zeiss epi-fluorescence microscope or an Olympus confocal laser scanning microscope for slides. Nuclear visualization was accomplished using DAPI Nuclear Counterstain Kit (Molecular Probes) or by covering slides with DAPI-containing mounting medium (Vector Laboratories).

\section{In situ hybridization for detection of human chondrocytes}

Whole-mount in situ hybridization of primary mesenchymal cultures was carried out as described before [25, 27]. Sense and antisense digoxigenin-incorporated riboprobes to human collagen type 9a2 (Co19a2) were prepared by in vitro transcription of a linearized EST clone (Accession number AI291668, obtained from MRC geneservice, Cambridge, UK) in which the 3' portion of the gene harboring the poly A sequence was deleted. This EST clone contains a region within the $3^{\prime}$ UTR that is not shared with the mouse Col9a2 gene. Riboprobes to mouse Co19a2 were prepared in a similar manner using an EST clone (Accession number BC029697, obtained from the MRC geneservice, Cambridge, UK) in which $\sim 1.5 \mathrm{~kb}$ of $3^{\prime}$ sequence was deleted, generating a $\sim 1.2 \mathrm{~kb}$ insert. All clones were verified by sequencing to confirm authenticity.

\section{Analysis of chondrocyte-specific gene expression in limb bud cultures}

De novo purified human cells, whole mouse cultures and mousehuman co-cultures were pelleted and used for mRNA isolation and cDNA synthesis (Amersham Biosciences). Amplification of transcripts was performed for 40 cycles using the following primer sets and annealing conditions. Aggrecan1: fwd. primer 5'-GGGTCAA- 
CAGTGCCTATCAG-3', rev. primer 5'-GGGTGTAGCGTGTAGAGATG-3', at $57^{\circ} \mathrm{C}$ for a 213 bp product (nested probe); Aggrecan 2: fwd. primer 5'-CCAAGAATCAAGTGGAGCCGTG-3', rev. primer 5'-GATGGGGTATCTGACAGTCTGGTC-3', at $65.2{ }^{\circ} \mathrm{C}$ for a 429 bp product. Amplified products were isolated and sequenced to verify the specificity of the gene amplification.

\section{Colony forming assays}

Human clonogenic progenitor assays were performed by plating 200-3000 purified cells into serum-free Methocult H4236 (Stem Cell Technologies) containing $300 \mathrm{ng} / \mathrm{ml} \mathrm{rhu}-$ Stem cell factor and Flt-3 ligand, $10 \mathrm{ng} / \mathrm{ml}$ rhu-Interleukin-6 and rhu-Interleukin-3, 50 $\mathrm{ng} / \mathrm{ml}$ Granulocyte-Colony Stimulating Factor and 3 units/ml rhuErythropoietin. Differential colony counts were assessed by morphology following incubations for $10-14 \mathrm{~d}$ at $37^{\circ} \mathrm{C}$ and $5 \% \mathrm{CO}_{2}$ in a humidified atmosphere.

\section{In vitro culture of purified human subpopulations}

Purified cells were placed in 96-well fibronectin-coated plates at 200-1500 cells per well. Media included mesencult media (Stem Cell Technologies), IMDM (GIBCO BRL) based media with BIT supplement (BSA, insulin, transferrin), M199 media (GIBCO BRL) with the following growth factors if desired; $10 \mathrm{ng} / \mathrm{ml} \mathrm{FGF}$ or EGF, hematopoietic growth factors include $300 \mathrm{ng} / \mathrm{ml} \mathrm{SCF}$ and Flt-3, $10 \mathrm{ng} / \mathrm{ml}$ interleukin- 3 and interleukin- 6 and $50 \mathrm{ng} / \mathrm{ml}$ granulocyte-colony stimulating factor, $25 \%$ human umbilical vein endothelial cell supernatant and $5 \%$ chick embryo extract. The day after seeding (d 1), the cells were counted in situ by bright-field microscopy to establish initial cell numbers and tracked for up to $32 \mathrm{~d}$.

\section{Mouse embryo collection}

Female 3-week old mice $[(\mathrm{Crl}: \mathrm{CD}-1 \AA(\mathrm{ICR}) \mathrm{BR})]$ were obtained from Charles River Canada, Inc (St. Constant, Quebec, Canada). Immature (3-6 weeks old) CD-1 females, were injected intraperitonealy (i.p.) with 5 i.u. Pregnant Mare Serum Gonadotropin (PMSG, Equinex: Ayerst, Montreal, QC, Canada.) in $1 \mathrm{ml}$ of $0.9 \%$ $\mathrm{NaCl}$ to induce follicular growth and mild superovulation. On $\mathrm{d} 0$ (11:00-11:30 am) they were injected intra-peritonealy (i.p.) with 5 i. u. human Chorio Gonadotropin (hCG, A.P.L*: Ayerst, Montreal, QC, Canada.) in $1 \mathrm{ml}$ of $0.9 \% \mathrm{NaCl}$ and paired with fertile CD-1 males. On d 3 for morulae or $\mathrm{d} 4$ for blastocysts, all females were killed by $\mathrm{CO}_{2}$ and oviducts and uteri excised and flushed with $\mathrm{M} 2$ Saline (PBS, GibCO, supplemented with $0.4 \%$ Bovine Serum Albumin (BSA, Sigma Chemical Co., St. Louis, MO, USA). The recovered embryos were set-up in culture dishes containing $\mathrm{kSOM}$ in a $\mathrm{CO}_{2}$ incubator.

\section{Injection or aggregation with murine blastocysts}

All injections and aggregations were performed using a micromanipulator (Narishige) and Hoffman Modulation contrast microscopy. Drops (50-100 $\mu \mathrm{l})$ of medium containing labeled human cells, were set up in $125 \mathrm{~mm}$ Petri dishes and performed on 8-cell stage embryos. Each embryo was immobilized by suction onto an embryo holding pipette and injected using a needle pre-loaded with 1-10 individual labeled $\mathrm{Lin}^{-} \mathrm{CD}^{4} 5^{-} \mathrm{CD} 34^{-}{ }^{-} \mathrm{Lin}^{-\mathrm{CD}} 34^{+} \mathrm{CD} 38^{-}$, or $\mathrm{CD} 33^{+}$cells in $\mathrm{kSOM}$ medium (http://www.mshri.on.ca/nagy/KSOM.HTML, Oct. 20, 2003). Embryos were then transferred to either a 96-well plate
( 1 embryo/well) containing $100 \mu \mathrm{l}$ of $\mathrm{kSOM}$ or to microwells in microdrops $(30 \mu \mathrm{l})$ of $\mathrm{kSOM}$ covered with sterile mineral oil and incubated at $37^{\circ} \mathrm{C}$ and at $95 \%$ air $5 \% \mathrm{CO}_{2}$. Aggregation of 8-cell stage embryos with the cells were performed as described in "Production of ES Cell Chimeras By Aggregation with Eight-Cell Stage Embryos", Mount Sinai hospital, Samuel Lunenfeld Research Institute (http://www.mshri.on.ca/develop/nagy/Diploid/diploid.htm). Briefly, the zona pellucida was dissolved and 1-5 labelled human cells were placed together in a microwell to permit contact and cultured overnight. For both methods, kSOM media was replenished $24 \mathrm{~h}$ post-injection and embryos were left to promote attachment. The cultures were then subjected to the following media changes: $\mathrm{MEM}+10 \% \mathrm{FCS}$ on $\mathrm{d} 2$ and $\mathrm{d} 3, \mathrm{MEM}+20 \% \mathrm{FCS}$ on $\mathrm{d} 4$, MEM $+10 \%$ FCS and $10 \%$ human cord sera (HCS) on d 5 , and $\mathrm{MEM}+20 \% \mathrm{HCS}$ on $\mathrm{d} 6$. Please note these experiments using human cell injections were performed prior to June 2000, nine months prior to the publication of the Canadian Institute of Health Research guidelines on the use of human stem cells and related assays for chimera formation on March 2001. Due to concerns raised in the guidelines, these experiments were not continued.

\section{RESULTS}

\section{Identification and characterization of Lin ${ }^{-} \mathrm{CD}^{-} 5^{-}$ cells in human cord blood}

The pan-leukocyte marker, CD45, is a receptor tyrosine phosphatase that is expressed on the majority of cells in the hematopoietic system and is absent in other tissues [28]. Hence, CD45 has been used as an indication of hematopoietic commitment [29]. To obtain the primitive Lin $^{-}$ population, CB cells are depleted of mature cells by negative selection which removes cells expressing protein surface markers of mature hematopoietic cells similar to that previously demonstrated [19]. Human CB Lin- cells were analyzed using FACS for expression of the hematopoietic marker, CD45. Viable cells were selected based on forward and side scatter properties (Fig. 1A) (gated R1) and the exclusion of the viability dye propidium iodide (Fig. 1B) (gated R2). When analyzed for the expression of CD45, the lineage depleted CB cells showed a heterogeneous expression of the pan-leukocyte marker with 3 distinct subpopulations. The majority of the cells $(56.9 \% \pm 4.6, \mathrm{n}=11)$ expressed CD45 at either a high MFI (Mean Fluorescence Intensity) of 662.25 or $(41.1 \% \pm 4.9, \mathrm{n}=1)$ moderate MFI of 132.10 (Fig. 1C). A small proportion of Lin $^{-}$cells were devoid of CD45 expression (Fig. 1C) and represented an average of $1.92 \% \pm 0.36(\mathrm{n}=11)$ of the total $\mathrm{Lin}^{-} \mathrm{CB}$ cells. Further analysis of these cells for expression of the primitive hematopoietic marker, CD34, revealed that the majority of CD45 cells were also absent for CD34 $(71.8 \% \pm 6.8$, $\mathrm{n}=9$ ). The absence of CD45 was in direct contrast to the expression of previously characterized $\mathrm{Lin}^{-} \mathrm{CD} 34^{+} \mathrm{CD} 38^{-}$ cells, which were nearly completely positive for moderate levels of CD45 $(99.0 \% \pm 0.6, n=11)$ (Fig. 1D), demonstrating that $\mathrm{Lin}^{-} \mathrm{CD} 34^{+} \mathrm{CD} 38^{-} \mathrm{HSCs}$ are $\mathrm{CD}^{-} 5^{+}$. Human 
A

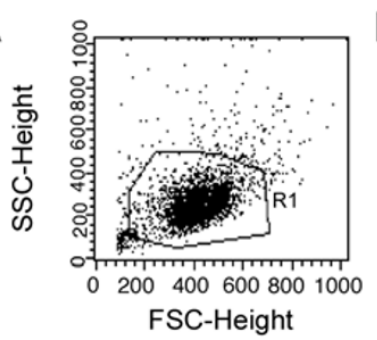

D

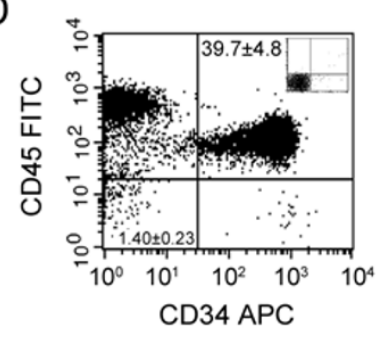

$\mathrm{F}$

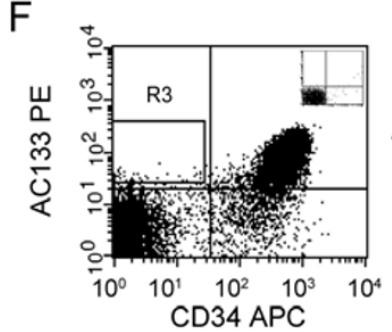

B

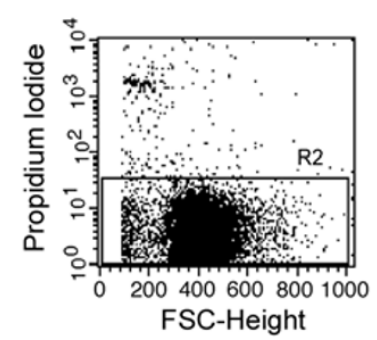

$\mathrm{E}$

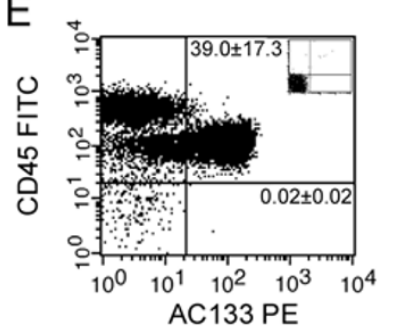

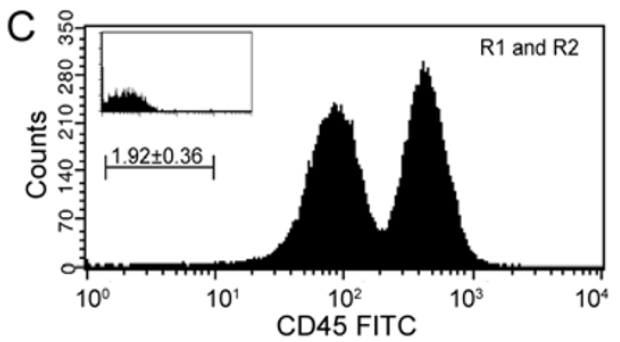

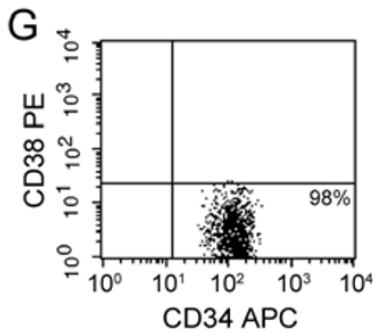

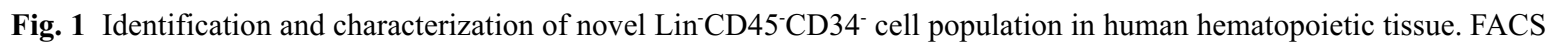
analysis of lineage depleted human umbilical cord blood cells was used to identify live cells based on (A) forward and sidescatter properties gated R1 and (B) exclusion of propidium iodide gated R2. (C) Live cells within R1 and R2 gates were then analyzed for expression of CD45, a marker indicative of hematopoietic commitment. (D) The majority of Lin ${ }^{-} \mathrm{CD} 45^{-}$cells lacked CD34. Percentage of subpopulations are shown as average mean \pm SEM. (E) Analysis of CD45 expression and AC133 ${ }^{+}$ cells, revealed that the majority of Lin ${ }^{-} \mathrm{CD}^{-} 5^{-}$cells do not express AC133 and furthermore, $(\mathbf{F})$ previously characterized Lin $^{-}$ $\mathrm{CD}^{-} \mathrm{AC}^{-} 33^{+}$gated R3, all express CD45. (G) Representative analysis of Lin ${ }^{-}$cells demonstrates the absence of CD38 on both $\mathrm{CD}^{-} 4^{-}$and $\mathrm{CD} 34^{+}$populations. Insets show isotype controls for each individual analysis $(\mathbf{C}-\mathbf{F})$.

CB populations also found within the lineage depleted fraction which lack CD34 but express the prominin AC133 $\left(\mathrm{Lin}^{-\mathrm{CD} 34} 4^{-} \mathrm{AC} 133^{+}\right)[30,31]$ are also capable of primitive hematopoietic function [21], however, the CD45 expression of these rarer Lin CD34 ${ }^{-} \mathrm{HSCs}$ has not been evaluated. Our analysis revealed that $\mathrm{Lin}^{-} \mathrm{CD} 45^{-} \mathrm{CD} 34^{-}$cells do not co-express AC133 (Fig. 1E). In addition, further characterization of $\mathrm{Lin}^{-} \mathrm{CD} 34^{-} \mathrm{AC} 133^{+}$cells revealed that all cells within this population express CD45, similar to in $^{-}$ $\mathrm{CD} 34^{+} \mathrm{CD} 38^{-}$cells (Fig 1F). All populations were found to lack the hematopoietic maturation marker, CD38, despite the presence or absence of CD34 or CD45 (Fig. 1G). We suggest that $\mathrm{CB} \mathrm{Lin}^{-} \mathrm{CD} 45^{-} \mathrm{CD} 34^{-}$cells represent a novel population that is phenotypically distinct from all other previously characterized subsets derived from human $\mathrm{CB}$ [21].

\section{Human Lin ${ }^{-C D 45}{ }^{-C D 34} 4^{-}$cells contribute to early cartilage condensations characteristic of chondrocyte precursors}

To determine if $\mathrm{Lin}^{-\mathrm{CD}} 45^{-\mathrm{CD}} 34^{-}$cells were capable of differentiation into a mesenchymal lineage, isolated subsets of human CB cells were co-cultured with primary embryonic murine limb bud cells and analyzed for chondrocytic cell fate potential. The murine cultures initially consist of a heterogeneous collection of mesenchymal cells, some of which become cartilage precursors or chondrocytes committed to cartilage formation as previously shown [32]. Such chondrocytes actively aggregate and exclude other cell types, resulting in condensations that appear to be nodules of high cell density among scattered individual mesenchymal cells [33]. Cells within the mesodermal condensations then differentiate into 
chondrocytes and begin production of cartilage specific glycosaminoglycans that can be identified by alcian blue staining $[26,34]$. Based on this murine assay for chondrogenic development, we surmised that co-culture of human cells with murine limb bud cells would allow for identification of human progenitors with chondrocytic potential.

To examine if $\mathrm{Lin}^{-\mathrm{CD}} 45^{-} \mathrm{CD} 34^{-}$cells possessed chondrocyte cell fate capacity, human Lin ${ }^{-} \mathrm{CD} 45^{-} \mathrm{CD} 34^{-}$cells were stained with the membrane dye PKH26 $[35,36]$ and co-cultured for $3 \mathrm{~d}$ with primary mouse limb bud cells and compared to $\mathrm{Lin}^{-} \mathrm{CD} 34^{+} \mathrm{CD} 38^{-}$cells known to be enriched for hematopoietic progenitors and HSCs. To assure that PKH26 dye transfer to mouse limb bud cells did not occur in this assay system, we labeled the membranes of putative mouse HSCs expressing Stem Cell Antigen-1 (Sca-1) [24], from the bone marrow of mice carrying the EGFP transgene [37]. These cells were stained with PKH26 and co-cultured with non-transgenic limb bud cells for $3 \mathrm{~d}$ after which, the cultures were analyzed for the co-expression of GFP and PKH26 using confocal microscopy. Results demonstrated that of the 50 PKH-labeled cells examined, all cells retaining the membrane dye (Fig. 2A b) were also co-expressing GFP (Fig. 2A a). The overlay of both fluorescent markers indicates that cells positive for the membrane dye PKH26 (red) were also GFP+ (Fig. 2 A c) and similarly, all GFP+ cells demonstrated PKH fluo-rescence. It is important to note that $\mathrm{PKH}+$ cells were only detected in the periphery and not in the nodules suggesting that despite their mouse origin, the highly purified cells possessing potent hematopoietic capacity may be unable to differentiate along the cartilage lineage. Unstained GFP+ cells were also used to establish levels of non-specific red fluorescence as an experimental control (Fig. 2A d-f). Thus, dye transfer does not occur in co-cultures of membrane labeled $\mathrm{PKH} 26+$ cells in this assay.

Given these controls for the integrity of the cell labeling and lack of dye transfer, which could lead to false positives in co-cultured conditions, subsets of human cells were co-cultured with limb bud cells and subsequently fixed and stained with alcian blue to reveal cartilage nodules (Fig. 2B a-c). Epi-fluorescence microscopy was used to follow the distribution of human cells within the cultures and to specifically detect the presence of human cells within cartilage nodules. Unlabeled cells were also used to establish background levels of fluorescence (Fig. 2B d). Labeled Lin ${ }^{-C D} 45^{-} \mathrm{CD} 34^{-}$cells could be detected within the cartilage nodules of the cultures (Fig. 2B e-h) exhibiting morphological features of differentiating chondrocytes such as an ovular cell shape (Fig. 2B g, h) and the absence of long processes characteristic of mesenchymal cell types (Fig. 2B 1). Detection of human cells in the nodules was not, however, restricted to the Lin $^{-} \mathrm{CD} 34^{-} \mathrm{CD} 45^{-}$cells.
Though the majority of labeled $\mathrm{Lin}^{-} \mathrm{CD} 34^{+} \mathrm{CD} 38^{-}$cells were excluded from the nodules, a very small proportion $(0.15 \%)$ could be detected within the nodules (Fig. 3C). Human cells lacking chondrocytic potential could also be detected among the layer of surrounding mesenchymal cells (Fig. 2B i), exhibiting the round, spherical shape characteristic of hematopoietic cells after co-culture with Lin ${ }^{-C D} 45^{-}$ CD34 cells (Fig. 2B j, k) and Lin $^{-} \mathrm{CD} 34^{+} \mathrm{CD} 38^{-}$(Fig. 2B $\mathrm{m}, \mathrm{n})$. This analysis suggests that $\mathrm{Lin}^{-} \mathrm{CD} 45^{-} \mathrm{CD} 34^{-}$cells possessed functional properties associated with chondrocytic potential by integration into murine nodules (Fig. 2B).

Detection of PKH-labeled human chondrocytes is unlikely to be due to cell fusion as previously documented cell fusion events could only be induced in long-term cultures in the presence of selective pressure [38-41]. The limb bud co-cultures were not subjected to such selective conditions and were maintained for a short period of three days, a time point at which cell fusion was previously not detected. Furthermore, limb bud cultures stained with DAPI revealed a single nuclear component (Fig. $2 \mathrm{C} \mathrm{a}, \mathrm{b}$ ) in cocultures containing human cells. Bi-nuclear cells were not observed in human and mouse limb bud cell co-cultures.

\section{Human Lin ${ }^{-C D 45}{ }^{-} \mathrm{CD}^{-} 4^{-}$cells demonstrate develop- ment programs of chondrocytic cell fate upon co-cul- ture with mouse embryonic mesenchymal cells in the presence of $\mathrm{BMP}-4$}

The number of human cells within the limb bud nodules was calculated for both $\mathrm{Lin}^{-} \mathrm{CD} 45^{-} \mathrm{CD} 34^{-}$cells and $\mathrm{Lin}^{-} \mathrm{CD} 34^{+} \mathrm{CD} 38^{-}$cells based on visual criteria to detect labeled cells within cartilage nodules (Fig. 2B). Quantitative analysis revealed that the number of the $\mathrm{Lin}^{-} \mathrm{CD} 45^{-}$ CD34- cells incorporated into the nodules was higher compared to Lin ${ }^{-} \mathrm{CD} 34^{+} \mathrm{CD} 38^{-}$cells and demonstrated the greatest potential in the presence of the TGF- $\beta$ superfamily ligand, BMP-4 (Fig. 3A).The addition of BMP-4 significantly increased the number of detectable human $\mathrm{Lin}^{-}$ CD45 CD34- cells within the nodules $(\mathrm{p}<0.005)$ compared to $\mathrm{Lin}^{-} \mathrm{CD} 34^{+} \mathrm{CD} 38^{-}$cells, suggesting this mesodermal factor may also be important to the differentiation of this novel population into cartilage precursors (Fig. 3A). The frequency of human chondrocytes from the $\mathrm{Lin}^{-} \mathrm{CD} 45^{-}$ CD34 cells in the presence of BMP-4 increased 5.3-fold compared to untreated cultures $(p<0.005)$ and also showed a significant increase compared to BMP-4 treated Lin $^{-}$ CD34 ${ }^{+}$CD38- cells $(\mathrm{p}<0.005)$.

To confirm development of human chondrocytic cells, co-cultures were assessed for the expression of cartilagespecific chondrocyte markers. Human CB populations were initially analyzed using RT-PCR for the cartilage specific transcript, Aggrecan (Agc), which is an abundant cartilage matrix protein expressed exclusively in later stages of 
A

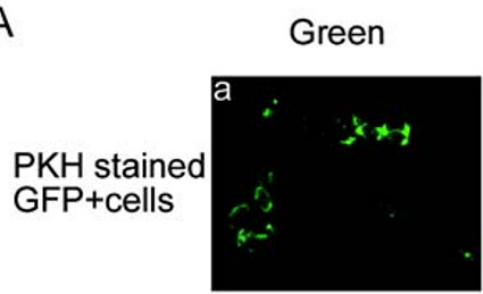

Red

Overlay
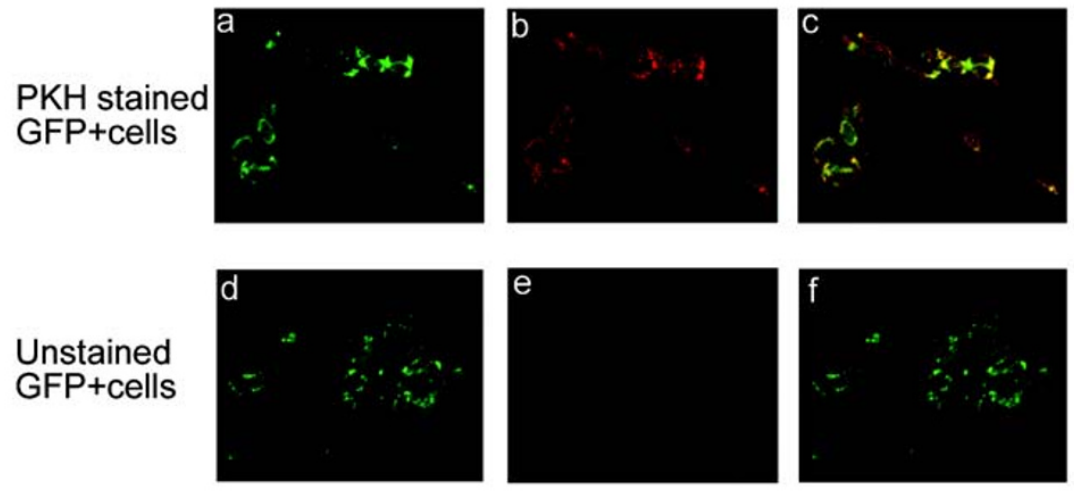

B
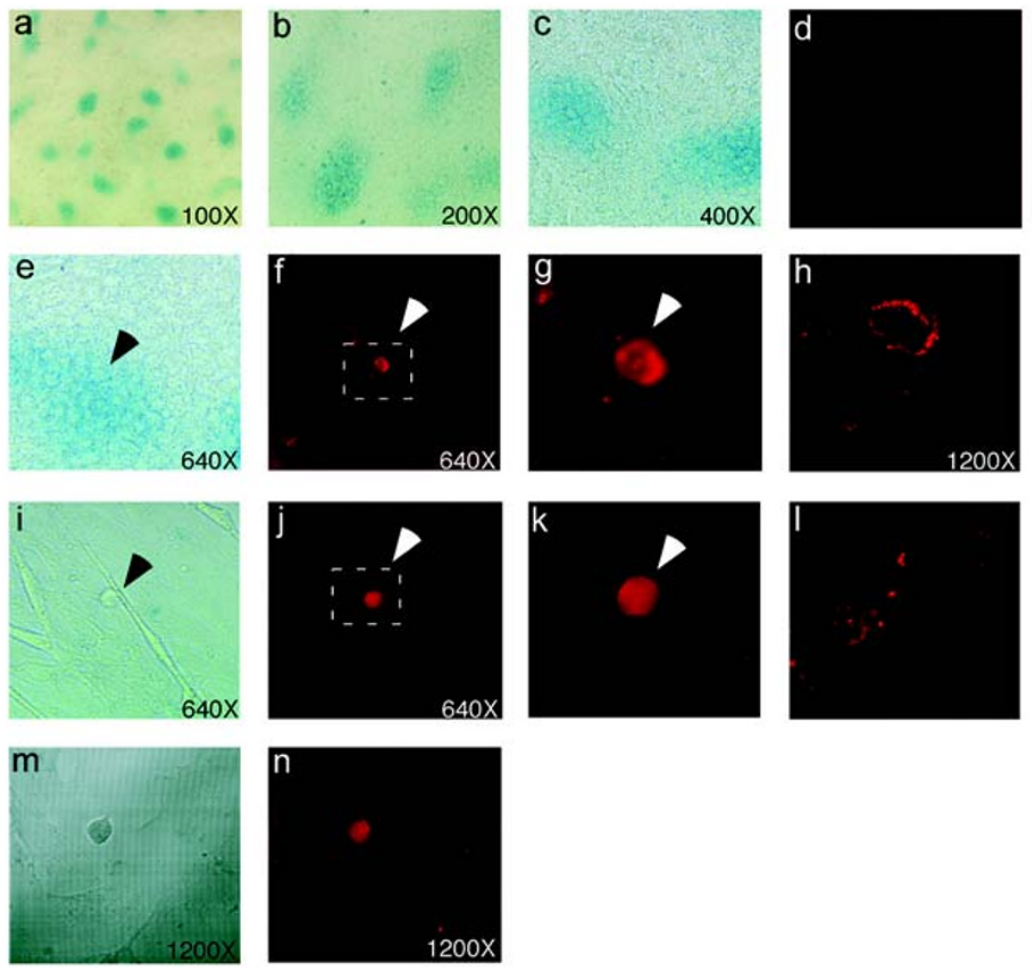

C

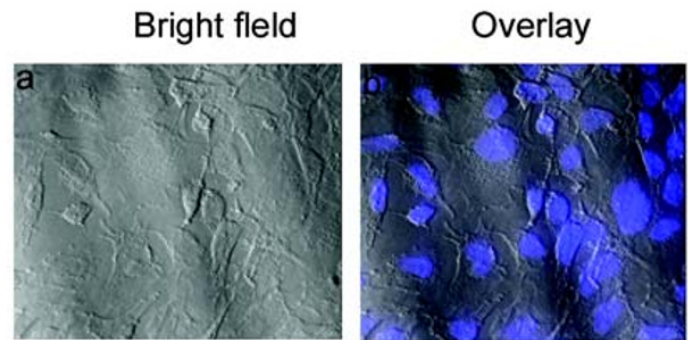


chondrocyte differentiation [42]. De novo Lin CD45-CD34 and $\mathrm{Lin}^{-} \mathrm{CD} 34^{+} \mathrm{CD} 38^{-}$cells displayed undetectable levels of $\mathrm{Agc}$ transcript as assessed by RT-PCR using human specific primers or following southern transfer and hybridization with a radiolabeled nested fragment of human Agc (Fig. 3B a, lanes 5, 6). No product was detected in mouse limb bud cultures alone, indicating the specificity of the analysis to human $\mathrm{Agc}$ transcripts only (Fig. 3B a, lanes 3,4). After co-culture with mouse limb bud cells, transcript for human $\mathrm{Agc}$ could be detected in Lin CD45 CD34- co-cultures (Fig. 3B a, lane 8). Human-mouse cocultures were also performed in the presence of BMP-4, which has been shown to stimulate cartilage production by increasing the number of chondrocyte nodules [25, 43]. It is of interest to note that $\mathrm{Agc}$ expression could only be detected in the presence of BMP-4 illustrating the importance of this morphogen in mediating cartilage development from Lin ${ }^{-C D} 45^{\circ} \mathrm{CD} 34^{-}$cells (Fig. 3B a, lane 8). Aggrecan transcript could not be detected in amplifications using mRNA from greater numbers of human cells to which reverse transcriptase was not added (Fig. 3B b). Thus, the product seen in the cultures containing human cells is most likely not due to DNA contamination. Similarly, detection of $\mathrm{Agc}$ in co-cultures with $\mathrm{Lin}^{-\mathrm{CD}} 34^{+} \mathrm{CD} 38^{-}$cells was only demonstrated in co-cultures in the presence of BMP-4 (data not shown), which is expected, as a small number of chondrocytes were detected in the co-cultures seeded with $\mathrm{Lin}^{-} \mathrm{CD} 34^{+} \mathrm{CD} 38^{-}$cells (Fig. 3A). Agc expression in $\mathrm{Lin}^{-} \mathrm{CD} 45^{\circ} \mathrm{CD} 34^{-}$cell co-cultures indicates that exposure to the mouse limb bud cells induces expression of a cartilage specific gene that is not expressed upon de novo isolation of this unique cell population

To provide further evidence that human $\mathrm{Lin}^{-\mathrm{CD}} 45^{-} \mathrm{CD} 34^{-}$ cells formed chondrocytes in the murine primary mesenchymal cultures, in situ hybridization was performed us- ing a human-specific Co19a2 probe. Type 2, 9 and 11 collagens are abundantly expressed in cartilage [42, 44, 45]. Scrutiny of these genes for regions specific to the human coding sequence revealed that the Col9a2 gene contained a large region ( $\sim 600 \mathrm{bp})$ within the 3 ' UTR that was not shared with its mouse counterpart, nor within the current version of the murine genome. For control purposes, cultures were hybridized with a mouse specific Co19a2 probe to identify regions in the cultures that contain Co19a2-expressing mouse cells. Similar to previous experiments, Lin $^{-}$ CD45 ${ }^{-}$D $34^{-}$cells were co-cultured only then assessed for human Co19a2 expression rather than membrane fluorescence. Instability of the PKH membrane dye caused by the reagents in the in situ protocol prevented simultaneous use of these two techniques, however, in situ analysis has previously been accepted as a reliable method for the detection of cartilage transcripts in the limb bud cultures [25]. Analysis of the murine cultures demonstrated that a subset of the cells, located in the central region of the nodules, expressed Co19a2 (Fig. 3C a). In contrast, this pattern of expression was not observed in the sense control probe (Fig. 3C b). The region of detection is consistent with the predicted expression pattern of Co19a2, which is typically expressed in slightly more mature chondrocytes [45] that would be distributed within the core of the nodules where the more differentiated cells reside. Some staining was observed in cells circumscribing the nodules, however, this also appeared in the sense controls demonstrating non-specific binding of the probe for Col9a2. In mixed human-mouse cultures containing human $\mathrm{Lin}^{-}$ CD45 ${ }^{-}$D $34^{-}$cells in the presence of BMP-4, human Co19a2 expression can be seen in small foci of cells within the nodules (Fig. 3C c, black arrow). Similar to the expression of $A g c$, human Co19a2 transcript could be detected in co-cultures containing $\mathrm{Lin}^{-} \mathrm{CD} 45^{-} \mathrm{CD} 34^{-}$compared to

\footnotetext{
4Fig. 2 LinCD45 CD34- cells exhibit chondrogenic potential upon co-culture with mouse limb bud cells. (A) Purified Sca-1+GFP+ mouse bone marrow cells were stained with PKH26 and co-cultured with limb bud cells to assess dye leakage. After culture, PKH positive cells could be detected in the peripheral areas (b) that co-expressed GFP (a). The overlay of PKH and GFP illustrates that cells that contain the membrane dye also express GFP (c). Cells not stained with PKH were also used in cultures resulting in the detection of cells that were only expressing GFP (d-f). (B) Lin ${ }^{-C D} 45^{-} \mathrm{CD} 34^{-}$and $\mathrm{Lin}^{-} \mathrm{CD} 34^{+} \mathrm{CD} 38^{-}$cells from 3 independent human $\mathrm{CB}$ samples were co-cultured for $3 \mathrm{~d}$ with murine limb bud cells and were then fixed and stained with alcian blue. Stained regions of cartilage nodules (blue) visualized by light microscopy (a, b). Higher magnification of nodules (c) and corresponding fluorescent visualization of unlabeled purified human cells for background control (d). Labeled human Lin ${ }^{-}$CD45 ${ }^{-}$D $34{ }^{-}$cells in cartilage nodules (f, $\mathbf{g}$, white arrows) that are surrounded by the alcian blue-stained matrix (e, black arrow). Co-cultured Lin ${ }^{-C D} 45^{-} \mathrm{CD} 34^{-}$cells located within the stained nodules exhibited chondrocyte-like morphology (f, g). Co-cultures were also seeded in chamber slides, fixed and mounted to confirm that labeled human Lin ${ }^{-C D} 45^{-}$CD34 cells within the cartilage nodules did adopt chondrocyte-like morphology using confocal microscopy (h). Lin ${ }^{-C D} 45^{-} \mathrm{CD} 34$ - cells could also be identified exhibiting round, hematopoietic cell morphology (j, k), and were excluded from nodules indicated by the lack of alcian blue staining (i). Labeled cells with mesenchymal cell morphology in non-cartilage regions could also be identified after co-culture (I) as well as Lin ${ }^{-C D} 34^{+} \mathrm{CD} 38^{-}$cells located outside cartilage nodules that maintained a round hematopoietic-like cell morphology $(\mathbf{m}, \mathbf{n})$. All images were captured from control or co-cultures containing $10 \mathrm{ng} / \mathrm{ml}$ BMP-4. (C) To assess the nuclear content, cells were stained with DAPI. Images of the cells in bright field using Hoffman optics (a) and the overlay of the DAPI stained regions (b) demonstrate the presence of a single nucleus in the co-cultures of approximately 200 cells examined.
} 
A

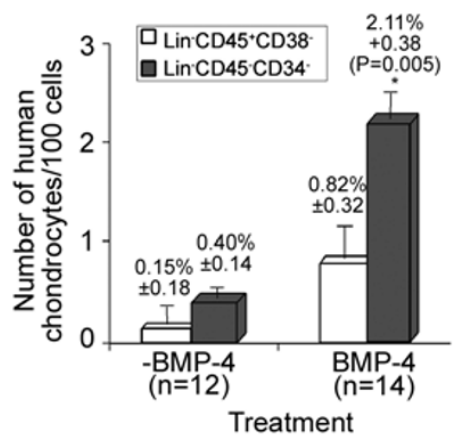

B

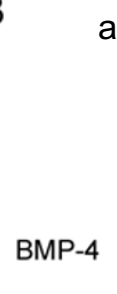

$\beta$-actin
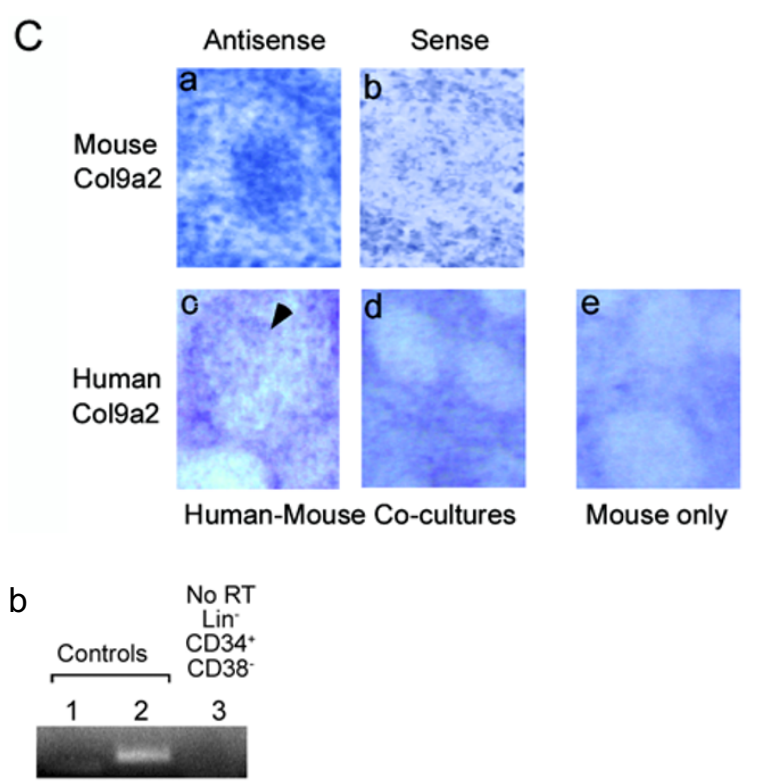

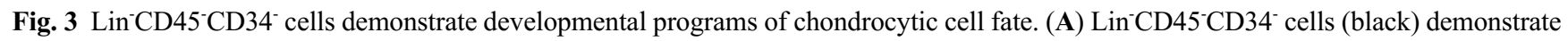
greater chondrogenic potential compared to Lin ${ }^{-} \mathrm{CD} 34^{+} \mathrm{CD} 38^{-}$cells (white) shown as the average number of human chondrocytes per 100 human cells seeded in the absence or presence of BMP-4. The calculated frequency of cells incorporated into the nodules, out of a total 1932 seeded for each population, is also shown as an average \pm SEM. (* = statistical difference at $p=0.005)$. (B) Detection of the cartilage specific transcript, Aggrecan by RT-PCR followed by southern hybridization (a) with a nested probe from mouse cells alone (lanes 3 and 4), de novo human $\mathrm{CB}$ populations (lanes 5 and 6), and co-cultures with human Lin ${ }^{-C D} 45^{-} \mathrm{CD} 34^{-}$cells (lanes 7 and 8 ). Analysis also included negative water control (lane 1) and positive control using fetal cDNA (lane 2). Amplification using mRNA from Lin ${ }^{-} \mathrm{CD} 34^{+} \mathrm{CD} 38^{-}$cells where RT was not added produced no product (b, lane 3) confirming the lack of DNA contamination. (C) Chondrocyte differentiation was further confirmed by in situ hybridization using an antisense probe specific to mouseCol9a2 (a) and corresponding sense-strand mouse probe (b) to ensure mRNA specificity. Using a human-specific antisense probe, expression of Col9a2 could be detected within the nodules of co-cultures containing Lin ${ }^{-}{ }^{-} 4^{\circ} \mathrm{CD} 34^{-}$cells and BMP-4 (c, black arrow), while the sense-strand probe was unable to hybridize (d). The human Co19A2 anti-sense probe showed a lack of staining in mouse only cultures eliminating the possibility of cross-species contamination (e).

mouse only cultures and required the presence of BMP-4. Using this human specific in situ probe, no staining was observed in regions around the nodules in the absence of human co-cultured cells. Control cultures using a human specific sense probe in mixed cultures (Fig. 3C d) or antisense probe in mouse-only cultures (Fig. $3 \mathrm{C} \mathrm{e}$ ) were both devoid of detectable staining within the nodules. Therefore, taken together, co-culture of human $\mathrm{Lin}^{-} \mathrm{CD} 45^{-} \mathrm{CD} 34^{-}$cells with mouse limb bud cells provides a suitable environment for the development of this human subset into chondrocytes. This is supported by a) functional identification of human cells within stained cartilage nodules, b) ability of human stained (PKH26+) cells to exhibit chondrocyte morphology, c) inducible expression of $A g c$ after co-culture with limb buds in conjunction with BMP-4 addition, and finally d) detection of human Col9a2 using a human specific probe for in situ hybridization of nodule co-cultures. Based on this series of experimental evidence, we suggest $\mathrm{Lin}^{-\mathrm{CD}} 45^{-} \mathrm{CD} 34^{-}$cells found in $\mathrm{CB}$ tissue possess developmental capacity towards the chondrocytic lineage.

\section{Human Lin ${ }^{-C D 45}{ }^{-}$CD34 $^{-}$cells are also capable of hematopoietic progenitor function and exhibit unique myelopoietic lineage potential}

$\mathrm{Lin}^{-} \mathrm{CD} 45^{\circ} \mathrm{CD} 34^{-}$cells present in $\mathrm{CB}$ were next assessed for functional hematopoietic capacity. Purified $\mathrm{Lin}^{-} \mathrm{CD} 45^{-}$

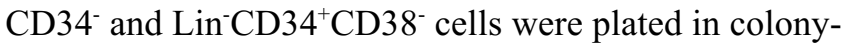
forming unit (CFU) assays to determine if these cells were capable of hematopoietic colony formation [46]. Surprisingly, 
A

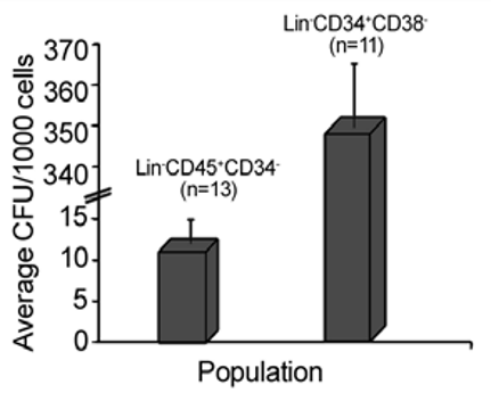

Plating efficiency: 1 in $100 \quad 1$ in 3.8

B

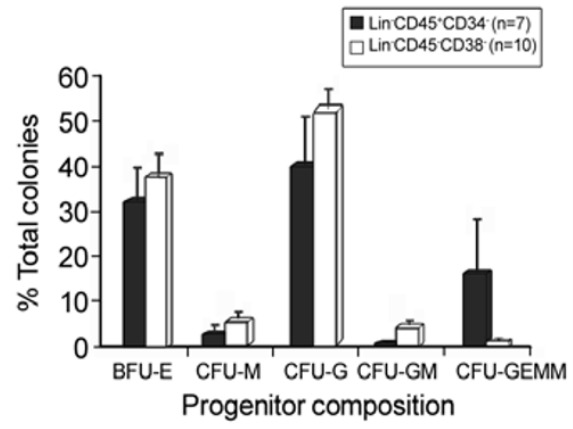

Fig. 4 Progenitor frequency and composition of novel Lin ${ }^{-C D} 45^{-}$ CD34- cells. (A) Purified Lin ${ }^{-}{ }^{-}{ }^{-} 5^{-}{ }^{-} D 34^{-}$and control Lin ${ }^{-C D} 34^{+}-$ CD38 cells were plated in colony-forming unit (CFU) assays for the detection of hematopoietic progenitors. Progenitor content is shown as the number of hematopoietic progenitors detected per 1000 cells plated \pm SEM. (B) Progenitor composition generated for Lin ${ }^{-C D} 45^{-}$ CD34- (grey) and $\mathrm{Lin}^{-} \mathrm{CD} 34^{+} \mathrm{CD} 38^{-}$cells (white) was calculated as the average percent of the total number of colonies \pm SEM for each colony type to identify differences in progenitor development. Colonies detected consisted of Burst-forming unit-Erythroid (BFU-E) and Colony Forming Units-Macrophage (CFU-M), -Granulocyte (CFU-G), Granulocyte-Macrophage (CFU-GM), and the tetrapotent unit able to form all colony types from a single progenitor (CFUGEMM).

cells phenotypically uncommitted to the hematopoietic lineage indicated by the lack of CD45 expression were capable of proliferation and differentiation characteristic of primitive hematopoietic progenitors (Fig. 4A). Quantitative analysis determined that 1 in 100 Lin $^{-} \mathrm{CD} 45^{-} \mathrm{CD} 34^{-}$cells was capable of hematopoietic progenitor func-tion. In comparison, the candidate human HSC population, $\mathrm{Lin}^{-}$ $\mathrm{CD} 34^{+} \mathrm{CD} 38^{-}$, which does express CD45, showed that this population was highly enriched for hematopoietic progenitors exhibiting a clonogenic efficiency of 1 in 3.8 (Fig. 4A), similar to previous reports $[19,47]$. Though the frequency of hematopoietic progenitors detected in the Lin CD45 CD34- cells was comparatively low to that of $\mathrm{Lin}^{-}$ CD $34^{+} \mathrm{CD} 38^{-}$cells, the Lin $^{-} \mathrm{CD} 45^{-} \mathrm{CD} 34^{-}$population was highly enriched for hematopoietic progenitors compared to unpurified hematopoietic cells. For example, the frequency of hematopoietic progenitors in unfractionated mononuclear cells from CB is approximately 1 in 2,100 and therefore, the $\mathrm{Lin}^{-} \mathrm{CD} 45^{-} \mathrm{CD} 34^{-}$population represents a greater than 20-fold enrichment compared to unpurified CB.

Interestingly, hematopoietic progenitor development of $\mathrm{Lin}^{-} \mathrm{CD} 45^{-} \mathrm{CD}^{-} 4^{-}$cells was distinct from the $\mathrm{Lin}^{-} \mathrm{CD} 34^{+}$ CD38- population. Quantitative clonal analysis to determine the percentage of each colony type derived for both $\mathrm{Lin}^{-} \mathrm{CD} 45^{-} \mathrm{CD}^{-} 4^{-}$and $\mathrm{Lin}^{-} \mathrm{CD} 34^{+} \mathrm{CD} 38^{-}$subsets was compared (Fig. 4B). Each population showed similar composition of the various hematopoietic colonies with the exception of the number of tetrapotent colonies. This type of colony develops from the proliferation and differentiation of a clonogenic progenitor (CFU) that is able to produce cells of four distinct hematopoietic lineages that include granulocytes, erythroid cells, macrophages, and mega-karocytes (GEMM) [48, 49]. As much as 13.5-fold greater frequency of tetrapotent CFU-GEMM progenitors arose from $\mathrm{Lin}^{-} \mathrm{CD} 45^{-} \mathrm{CD} 34^{-}$cells compared to $\mathrm{Lin}^{-}$ $\mathrm{CD}^{+} 4^{+} \mathrm{CD} 38^{-}$cells (Fig. $4 \mathrm{~B}, \mathrm{p}<0.01$ ). Therefore, unlike adult BM derived CD45 cells, $\mathrm{CB}$ derived Lin ${ }^{-} \mathrm{CD} 45^{\circ} \mathrm{CD} 34^{-}$ cells possess hematopoietic progenitor capacity and furthermore, display unique primitive hematopoietic cell fate potential compared to previously characterized $\mathrm{CB}$ populations.

Transplantation studies revealed that $\mathrm{Lin}^{-\mathrm{CD}} 45^{-} \mathrm{CD} 34^{-}$ cells were unable to reconstitute the bone marrow of immune deficient mice, although chimerism could be detected in several tissues by southern analysis using a radiolabeled human specific fragment of a chromosome 17 alphasatellite repeat region to detect human DNA in the organs of transplanted mice (data not shown). Results showed that one of three mice transplanted had detectable human chimerism in the liver, lung and spleen. Accordingly, although $\mathrm{Lin}^{-\mathrm{CD}} 45^{-} \mathrm{CD} 34^{-}$cells are capable of primitive hematopoietic progenitor function, it is unclear if these cells also possess pluripotent hematopoietic stem cell properties detectable in adult recipient mice.

\section{Murine blastocysts provide a suitable environment for the survival and proliferation of primitive $\mathrm{Lin}^{-}$ CD45-CD34- cells}

In vitro culture conditions for $\mathrm{Lin}^{-\mathrm{CD}} 34^{+} \mathrm{CD} 38^{-}$cells have previously been optimized for the expansion of these cells using serum-free medium containing several hematopoietic factors. Lin ${ }^{-} \mathrm{CD} 45^{-} \mathrm{CD} 34^{-}$cells were cultured in the same conditions used for $\mathrm{Lin}^{-} \mathrm{CD} 34^{+} \mathrm{HSC}$, however, the $\mathrm{Lin}^{-} \mathrm{CD} 45^{-} \mathrm{CD} 34^{-}$cells could not be maintained in human HSC supportive-conditions. Further characterization of the Lin ${ }^{-}{ }^{-} 5^{-} \mathrm{CD}^{-}$cells was hindered by the inability to iden- 
A

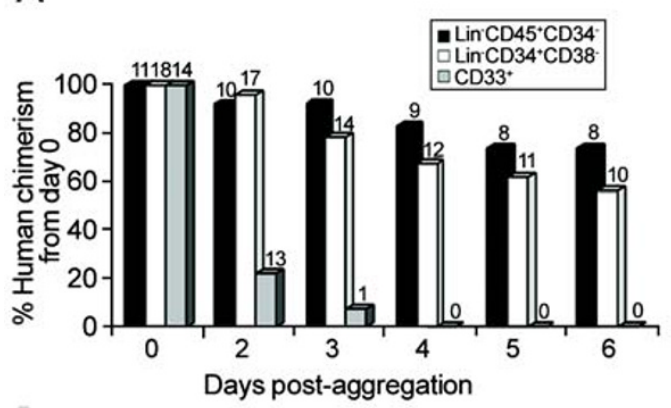

D

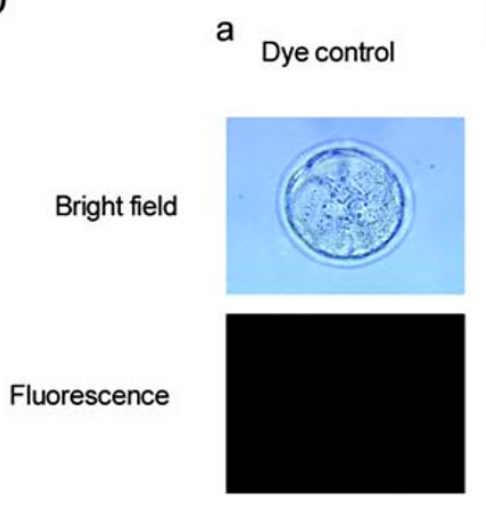

B

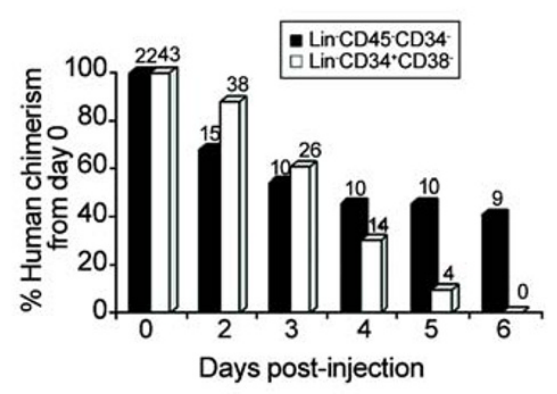

b

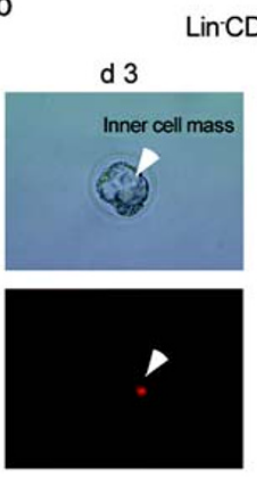

C

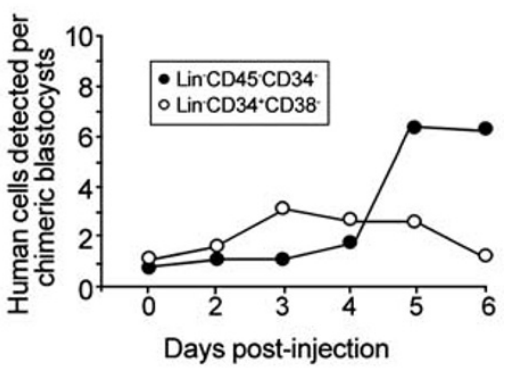

Lin'CD34+CD38-
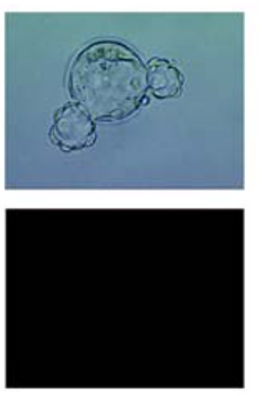

Fig. 5 Aggregation or injection with murine blastocysts promotes greater survival of Lin ${ }^{-C D} 45^{-} \mathrm{CD} 34^{-}$cells. Labeled Lin ${ }^{-} \mathrm{CD}^{-} 5^{-} \mathrm{CD} 34^{-}$(black), $\mathrm{Lin}^{-} \mathrm{CD} 34^{+} \mathrm{CD} 38^{-}$(white) and committed $\mathrm{CD}_{3} 3^{+}$myeloid cells (grey) from 2 independent $\mathrm{CB}$ samples were used for aggregation or single cell injection with murine CD1 blastocysts. Total number of individual blastocysts containing human cells integrated into the inner cell mass (ICM) is shown $2 \mathrm{~d}$ after (A) aggregation (B) injection and each day thereafter for a total period of $5 \mathrm{~d}$. Absolute numbers of chimeric blastocysts are shown above individual bar graphs with $\mathrm{d} 0$ numbers representing the number of successful aggregation or injection attempts. (C) A comparison of Lin ${ }^{-} \mathrm{CD} 45^{-} \mathrm{CD} 34^{-}$and $\mathrm{Lin}^{-} \mathrm{CD} 34^{+} \mathrm{CD} 38^{-}$cell integration and proliferation is shown as the average number of cells detected per human-mouse chimeric blastocyst after single cell injections. (D) Representative pictures of control blastocyst $3 \mathrm{~d}$ after injection with medium from stained cells (a) under bright field or fluorescence microscopy to establish dye specificity. Labeled human Lin $^{-} \mathrm{CD}^{-{ }^{-} \mathrm{CD} 34^{-} \text {cell }}$ (b, left) shown integrated with ICM after single cell injection and corresponding bright field picture. At d 6 (b, right), the same embryo has begun the hatching process in which the ICM separates from the zona pellucida. Intact labeled Lin ${ }^{-} \mathrm{CD}^{-} 5^{-} \mathrm{CD} 34^{-}$cells could still be detected $6 \mathrm{~d}$ after single cell injection while hatching embryos injected with (c) a single Lin ${ }^{-} \mathrm{CD} 34^{+} \mathrm{CD} 38^{-}$could not be detected containing intact labeled human cells.

tify an in vitro environment that could support this population. Cells were cultured in serum-free medium and serum-containing media with added hematopoietic growth factors, fibroblast growth factor (bFGF), chick embryo extract, human umbilical vein endothelial cell conditioned media (HUVEC), and media optimized for mesenchymal cells [50, 51]. In all conditions, cell counts declined rapidly over time and sufficient numbers for subsequent analysis were unobtainable (data not shown). In contrast, after $8 \mathrm{~d}$, $\mathrm{Lin}^{-} \mathrm{CD} 34^{+} \mathrm{CD} 38^{-}$cells proliferated 10 -fold or greater in all conditions used with the exception of the mesenchymal cell medium (data not shown). Despite failure to maintain these cells in various culture conditions, presence of $\mathrm{Lin}^{-}$ $\mathrm{CD} 45^{-\mathrm{CD}} 34^{-}$cells or derivatives generated by co-culture with embryonic limb buds suggests that a primary embry- onic environment may be required for the survival of these human CB cells.

To further examine the survival of human CB subsets, purified cells were injected or aggregated with blastocysts from immune-competent CD1 mice to determine if these human cells could persist within the embryonic environment by integrating with the ICM. Initial experiments were performed where integration of labeled human cells with murine blastocyst cells was accomplished by cellular aggregation. $\mathrm{Lin}^{-} \mathrm{CD} 45^{-} \mathrm{CD} 34^{-}$and $\mathrm{Lin}^{-} \mathrm{CD} 34^{+} \mathrm{CD} 38^{-}$cells were stained with PKH26 membrane dye and 1-4 human cells were aggregated with a single murine blastocyst after removal of the zona pellucida. For comparison, a mature myeloid population expressing CD33 was also stained and assayed in the same manner. Cells were allowed to aggre- 
gate for $2 \mathrm{~d}$ after which the number of blastocysts containing a fluorescent human cell was tracked over the next $5 \mathrm{~d}$. Media from stained cells was also used for injection to assure that dye leakage would not affect the definitive detection of the human cells (Fig. 5D a). The number of blastocysts with human cells steadily declined following aggregation with all populations. After $48 \mathrm{~h}, \mathrm{CD}_{3} 3^{+}$mature myeloid cells displayed a rapid decrease with only $10 \%$ of the aggregated blastocysts having detectable integrated human cells (Fig. 5A, grey bars). In contrast, both primitive populations displayed a higher rate of survival than the mature $\mathrm{CD} 33^{+}$population throughout the culture period. Lin ${ }^{-C D} 45^{-} \mathrm{CD} 34^{-}$cells exhibited the greatest microchimerization potential as more than $70 \%$ of the initial blastocysts still contained at least one human cell by the end of the tracking period after aggregation (Fig. 5A, black bars). Lin ${ }^{-} \mathrm{CD} 34^{+} \mathrm{CD} 38^{-}$cells declined further with $56 \%$ of the chimerized blastocysts persisting by $\mathrm{d} 6$ (Fig. 5A, white bars). This data suggests that the Lin $^{-}$ CD45 ${ }^{-} \mathrm{CD} 34^{-}$cells may possess a survival advantage in the mouse embryo, although in some cases aggregations were performed with multiple human cells. Furthermore, this assay appears to support primitive human cells such as the $\mathrm{Lin}^{-} \mathrm{CD} 45^{-} \mathrm{CD} 34^{-}$and $\mathrm{Lin}^{-} \mathrm{CD} 34^{+} \mathrm{CD} 38^{-}$cells while mature cells, such as the $\mathrm{CD} 33^{+}$population, could not be maintained. Hence the chimeric blastocysts provide a system that selectively allows for the study of primitive human cells and candidate HSC.

To determine the response of each cell population at a clonal level, $\mathrm{Lin}^{-} \mathrm{CD} 45^{-} \mathrm{CD} 34^{-}$and $\mathrm{Lin}^{-} \mathrm{CD} 34^{+} \mathrm{CD} 38^{-}$cells were stained in the same manner and used for single cell injection. The number of detectable Lin $^{-} \mathrm{CD} 34^{+} \mathrm{CD} 38^{-}$cells within a blastocyst dropped to less than $5(9.3 \%)$ after $5 \mathrm{~d}$, despite an initial total number of 43 successfully injected blastocysts at d 0 (Fig. 5B, white bars). By the last day of tracking (d 6), no Lin ${ }^{-C D} 34^{+} \mathrm{CD} 38^{-}$cells were detected within the murine blastocysts (Fig. 5D c). Lin ${ }^{-C D} 45^{-}$CD34cells declined more slowly with approximately $55 \%$ of injected blastocysts still containing at least one detectable human cell after $3 \mathrm{~d}$ (Fig. 5D b). This proportion dropped minimally over the rest of the culture period, reaching $41 \%$ of the total by d 6 (Fig. 5B, black bars). The frequency of survival of $\mathrm{Lin}^{-} \mathrm{CD} 45^{-} \mathrm{CD} 34^{-}$cells was therefore greater than $\mathrm{Lin}^{-} \mathrm{CD} 34^{+} \mathrm{CD} 38^{-}$cells ( $\sim 4.9$-fold) by d 5, indicating that the $\mathrm{Lin}^{-} \mathrm{CD} 45^{\circ} \mathrm{CD} 34^{-}$cells exhibit greater responsiveness to the murine embryonic environment. Interestingly, the survival of the $\mathrm{Lin}^{-} \mathrm{CD} 34^{+} \mathrm{CD} 38^{-}$cells was greater when chimerization was achieved through aggregation suggesting that these cells may require co-operativity or interaction to survive.

Using two independent methods for microchimerization, we have shown that the responsiveness of cells to an en- vironment provided by an intact embryo is greatest in the $\mathrm{Lin}^{-} \mathrm{CD} 45^{-} \mathrm{CD}^{-} 4^{-}$population similar to the results seen in the chondrocyte assays. Thus, these primary cell environments may be providing the crucial signals required by a very primitive population, which cannot be recapitulated by current in vitro techniques. Furthermore, the murine blastocyst environment also appears to promote the proliferation of the chimerized human cells. Results showed that the number of detectable human Lin ${ }^{-C D} 45^{-}$CD34- cells within a single blastocyst after single-cell injection increased over time with a 6-fold increase in cell number by $\mathrm{d} 5$ and d 6 (Fig. 5C). In contrast, Lin ${ }^{-} \mathrm{CD} 34^{+} \mathrm{CD} 38^{-}$cells displayed limited proliferative potential initially increasing 3 -fold at $\mathrm{d}$ 3 but eventually declining back to one detectable cell per chimerized blastocyst. A limitation of using visual microscopy to detect and quantify the number of surviving cells is that we are unable to unequivocally ascertain if the cells are in fact viable though the detected cells persist and appear to have intact viable morphology. The low number of detectable $\mathrm{CD}_{3} 3^{+}$cells, a mature population with known limited survival, and the decline of detectable cells over time suggests that cells that do not survive most likely degrade and are undetectable as there was no evidence of labeled cell fragments in any of the cultures. Furthermore, the expansion of Lin $^{-} \mathrm{CD}^{-} 5^{-} \mathrm{CD} 34^{-}$cells after single-cell injection, a subpopulation that could not be maintained in conventional culture media, would argue that the cells are viable and more importantly proliferating, at least until d 3 when in contact with a blastocyst. Without the use of ethically prohibited functional experiments via in utero transplantation into surrogate murine hosts, the function and definitive viability of the chimerized cells cannot be demonstrated. The combination of the data demonstrating greater persistence of the primitive populations as well as proliferation suggests that the cells survive and in the case of the Lin ${ }^{-} \mathrm{CD} 45^{-} \mathrm{CD} 34^{-}$cells, are provided with an environment that is more favorable than previously reported methods. Using this system, we have shown that the newly identified $\mathrm{Lin}^{-\mathrm{CD}} 45^{-} \mathrm{CD} 34^{-}$population is able to persist and microchimerize the murine blastocysts, has a greater survival rate as well as superior potential for proliferation than other primitive and mature subsets.

\section{DISCUSSION}

Our report demonstrates the identification of a novel human cell population which is distinct from previously characterized CB populations and capable of hematopoietic and chondrocytic differentiation. The two populations studied here ( $\mathrm{Lin}^{-} \mathrm{CD} 45^{-} \mathrm{CD} 34^{-}$and $\mathrm{Lin}^{-} \mathrm{CD} 34^{+} \mathrm{CD} 38^{-}$) share overlapping functional features, although the extent of their potential is unique. Previously characterized Lin $^{-}$ CD $34^{+} \mathrm{CD} 38^{-}$cells are capable of extensive hematopoietic 
potential in vivo and in vitro $[18,52]$. The chondrogenic potential of these cells is limited and hence the majority of $\mathrm{Lin}^{-} \mathrm{CD} 34^{+} \mathrm{CD} 38^{-}$cells appear to be committed to hematopoietic differentiation. In contrast, the $\mathrm{Lin}^{-} \mathrm{CD} 45^{-} \mathrm{CD} 34^{-}$ cells display a lower hematopoietic potential, yet displayed a higher frequency of the most primitive colony type. The Lin-CD45-CD34- cells, however, contained a comparatively greater number of chondrocyte precursors and hence hematopoietic differentiation may not be the dominant developmental pathway for this cell population. In addition, the absence of CD45 expression of these novel cells suggests that although they are derived from human cord "blood", they are not committed to hematopoietic fate since the anatomical location from which they are obtained does not define their lineage potential. Accordingly, the ability of $\mathrm{Lin}^{-} \mathrm{CD} 45^{-} \mathrm{CD} 34^{-}$cells to give rise to chondrocytic and hematopoietic cells is unrelated to arguments regarding the controversial area of transdifferentiation phenomena. It is important to note that the chondrogenic potential of the Lin ${ }^{-C D} 45^{-} \mathrm{CD} 34^{-}$cells may not necessarily be representative of their in vivo function and therefore, may be an ex vivo phenomenon. This, however, does not necessarily lower the utility of the function that the cells exhibit once outside their native environment. Once differentiated in culture, these cells may still demonstrate therapeutic use. For example, human or mouse ES cells that may have therapeutic potential are not found in vivo and require in vitro culture [53-55].

Despite the identification of this novel population of human CB derived cells, our current findings do not conclusively determine if the resulting differentiated hematopoietic cells and chondrocytes arise from a single common precursor cell or whether the $\mathrm{LinCD}^{-} \mathrm{C} 45^{-} \mathrm{CD} 34^{-}$population is comprised of co-existing hematopoietic and chondrogenic precursors. In the absence of identifying retroviral integration sites common to both hematopoietic and chondrocytic progeny differentiated from $\mathrm{Lin}^{-} \mathrm{CD} 45^{-} \mathrm{CD} 34^{-}$cells or single clonal culture assays, we are unable to support either theory. As demonstrated here, culture conditions required to maintain these novel cells for a limited period are not available, and therefore neither of these strategies is feasible based on our current knowledge of this novel population. However, since the mouse blastocyst environment provides some beneficial effects on the survival of Lin CD $45^{-} \mathrm{CD} 34^{-}$cells, future directions towards the ex vivo culture of these cells and subsequent clonal analysis should be focused on candidate factors present during this stage of mammalian embryonic development.

Determining whether the Lin ${ }^{-C D} 45^{-} \mathrm{CD} 34^{-}$cells are able to produce $\mathrm{CD} 45^{+}$cells with functional similarities to the Lin ${ }^{-} \mathrm{CD} 34^{+} \mathrm{CD} 38^{-}$population will provide insights into the relationship and hierarchical organization among these subsets. Such studies, however, have been hindered by the inability to maintain the $\mathrm{Lin}^{-} \mathrm{CD} 45^{-} \mathrm{CD} 34^{-}$cells in culture. The morphogen, BMP-4, may be a candidate factor for the development of the $\mathrm{Lin}^{-} \mathrm{CD} 45^{-} \mathrm{CD} 34^{-}$cells as the presence of this protein significantly increased their cartilage potential. The exact role of BMP-4 on the novel Lin ${ }^{-C D} 45^{-}$ CD34- population requires further characterization, as this factor alone is not sufficient, since cultures with added BMP-4 could not induce proliferation of Lin ${ }^{-C D} 45^{-} \mathrm{CD} 34^{-}$ cells (data not shown). This factor has been implicated in the development of mesodermal cell fates [56-59]. Treatment with BMP-4 has also been shown to increase the number of progenitors in the $\mathrm{Lin}^{-} \mathrm{CD} 34^{+} \mathrm{CD} 38^{-}$population and prolong the survival of these candidate HSCs [60]. In addition, the BMP pathway has been shown to be important to murine chondrogenesis $[61,62]$ as well as human fracture repair [63]. Both $\mathrm{Lin}^{-} \mathrm{CD} 45^{-} \mathrm{CD} 34^{-}$and $\mathrm{Lin}^{-} \mathrm{CD} 34^{+}-$ CD38- cells express both type I BMP receptors, ALK-3 and ALK-6 (data not shown), however, we are unable to conclude if the cells expressing the BMP receptors are the same cells that are located within the nodules. At this point, the mechanism by which BMP increases the detection of human cells within the nodules is unknown. The BMP protein may directly affect the human cells or simply target the murine cells to allow a more favorable environment to the labeled human cells. Therefore, though the mechanism is unknown, our results demonstrate that similar to the effect documented in the mouse system [25], BMP-4 also causes an increase in cartilage development and differentiation of human chondrogenic precursors.

\section{Multipotent capacity of mammalian cells and embryonic environments}

Lin ${ }^{-C D} 45^{-} \mathrm{CD} 34^{-}$cells share characteristics with recently reported mesodermal progenitor cells (MPCs) isolated from BM that are also devoid of CD34 and CD45 expression [9, 64]. The differentiation potential of MPCs is dependent on the culture conditions demonstrating the importance of the inductive signals required for tissue differentiation. MPCs were unable to produce hematopoietic cells yet can be used as a support system for purified hematopoietic cells [65]. Cells resident in the BM with non-hematopoietic potential may indicate the existence of a common ancestor that possesses properties of both primitive hematopoietic and mesenchymal cells. However, initial studies were unable to demonstrate a mesenchymal stem cell with hematopoietic potential $[8,9]$. Mouse bone marrow cells, termed multipotent adult progenitor cells (MAPCs), have now been identified which demonstrate pluripotency after integration with murine blastocysts and transfer into foster mothers to produce chimeric offspring [66]. In addition, the embryonic environment may be crucial to the inductive 
process of tissue specification as injected neural stem cells are able to chimerize the embryo and contribute to the formation of other tissues such as heart and liver [67]. Hence, this early embryonic environment appears to provide the proper environment for demonstrating multipotentiality of this adult derived mammalian cell population.

Human Lin ${ }^{-C D} 45^{-}$CD $34^{-}$cells identified here are distinct from previously identified adult BM-derived CD45cells $[8,9,66]$ in that they display de novo hematopoietic function. In addition, in contrast to MAPCs, LinCD45CD34- cells derived from $\mathrm{CB}$ can be prospectively isolated, and do not require serial passages in vitro for derivation. The importance of embryonic environments appears to be crucial to the differentiation and survival of Lin ${ }^{-} \mathrm{CD} 45^{-}$ CD34- cells as attempts to maintain these cells in culture using a variety of media were unable to support these cells. The LinCD45'CD34- cells displayed greater differentiation potential in the presence of primary embryonic tissue, such as limb bud cultures, and greater survival and proliferative capacity upon integration with murine blastocysts compared to $\mathrm{Lin}^{-} \mathrm{CD} 34^{+} \mathrm{CD} 38^{-}$cells. This assay may serve as an efficient new model for examining cells with primitive cell proliferation and differentiation potential that is able to mimic unique embryonic environments required for candidate stem cells that may possess multipotent differentiation capacity, thereby providing an alternative to measure cell fate ability of newly identified human stem cells. By providing extrinsic factors not available to adult specified stem cells, murine blastocysts chimerized with human cells may provide insights into early developmental events of human cells using in situ techniques for the detection of genes critical to stem cell regulation. In addition, chimerized blastocysts may be used for transfer into foster mothers so that the human cells may be studied in an in vivo environment. The early embryonic environment can also be assessed for a role in cellular re-programming by determining if exposure to the blastocyst cells changes the gene expression profile of the injected cells. The use of fluorescent dyes shown in our current study allows the human cells to be tracked as well as a marker for isolation using flow cytometric isolation. Adaptation of this system in experiments aimed to characterize primitive populations may reveal undiscovered cellular potentials of adult human cells that were previously undetectable due to limitations of currently used models such as xeno-transplantation into adult recipients. In addition, by using blastocysts from mutant mice with gene deletions or overexpressing specific transgenes, this assay creates a powerful tool for examining extrinsic regulatory factors hypothesized to be important for adult human stem cell regulation and in vivo cell fate induction. Our current study illustrates the importance of using this assay for the characterization of novel stem cell populations derived from human sources. The cellular potential of the $\mathrm{Lin}^{-} \mathrm{CD} 45^{-} \mathrm{CD} 34^{-}$cells identified here could only be detected in the presence of an embryonic environment and hence this assay will be a focus for further characterization of this and other novel human stem cell populations in our laboratory.

\section{ACKNOWLEDGEMENTS}

This work was supported by a grant from the Canadian Institutes of Health Research, Ontario, Canada (No. MT15063) and The Krembil Foundation, a Canadian Research Chair award in Stem Cell Biology and Regenerative Medicine and Krembil Chair in Stem Cell Biology to MB, and studentship to KJ from the Stem Cell Network, Canadian National Centre of Excellence Program.

Received, Apr 5, 2004

Revised, May 19, 2004

Accepted, May 24, 2004

\section{REFERENCES}

1 Abramson S, Miller RG, Phillips RA. The identification in adult bone marrow of pluripotent and restricted stem cells of the myeloid and lymphoid systems. J Exp Med 1977; 145:1567-79.

2 Barr RD, Whang PJ, Perry S. Hemopoietic stem cells in human peripheral blood. Science 1975; 190:284-5.

3 Gluckman E, Broxmeyer HA, Auerbach AD, et al. Hematopoietic reconstitution in a patient with Fanconi's anemia by means of umbilical-cord blood from an HLA-identical sibling. N Engl J Med 1989; 321:174-8.

4 Broxmeyer HE, Kurtzberg J, Gluckman E, et al. Umbilical cord blood hematopoietic stem and repopulating cells in human clinical transplantation. Blood Cells 1991; 17:313-29.

5 Friedenstein AJ, Petrakova KV, Kurolesova AI, Frolova GP. Heterotopic of bone marrow. Analysis of precursor cells for osteogenic and hematopoietic tissues. Transplantation 1968; 6: 230-47.

6 Luria EA, Owen ME, Friedenstein AJ, Morris JF, Kuznetsow SA. Bone formation in organ cultures of bone marrow. Cell Tissue Res 1987; 248:449-54.

7 Bruder SP, Gazit D, Passi-Even L, Bab I, Caplan AI. Osteochondral differentiation and the emergence of stage-specific osteogenic cell-surface molecules by bone marrow cells in diffusion chambers. Bone Miner 1990; 11:141-51.

8 Pittenger MF, Mackay AM, Beck SC, et al. Multilineage potential of adult human mesenchymal stem cells. Science 1999; 284: 143-7.

9 Reyes M, Lund T, Lenvik T, et al. Purification and ex vivo expansion of postnatal human marrow mesodermal progenitors cells. Blood 2001; 98:2615-25.

10 Erices A, Conget P, Minguell JJ. Mesenchymal progenitor cells in human umbilical cord blood. Br J Haematol 2000; 109:235-42.

11 Mareschi K, Biasin E, Piacibello W, et al. Isolation of human mesenchymal stem cells: bone marrow versus umbilical cord blood. Haematologica 2001; 86:1099-100. 
12 Wexler SA, Donaldson C, Denning-Kendall P, et al. Adult bone marrow is a rich source of human mesenchymal 'stem' cells but umbilical cord and mobilized adult blood are not. Br J Haematol 2003; 121:368-74.

13 Zvaifler NJ, Marinova-Mutafchieva L, Adams G, et al. Mesenchymal precursor cells in the blood of normal individuals. Arthritis Res 2000; 2:477-88.

14 Morrison SJ, Uchida N, Weissman IL. The biology of hematopoietic stem cells. Annu Rev Cell Dev Biol 1995; 11:35-71.

15 Orkin SH. Hematopoiesis: how does it happen? Curr Opin Cell Biol 1995; 7:870-7.

16 Harris DT, Schumacher MJ, LoCascio J, et al. Immunoreactivity of umbilical cord blood and post-partum maternal peripheral blood with regard to HLA-haploidentical transplantation. Bone Marrow Transplant 1994; 14:63-8.

17 Broxmeyer HE. Cord blood as an alternative source for stem and progenitor cell transplantation. Curr Opin Pediatr 1995; 7:47-55.

18 Bhatia M, Wang JC, Kapp U, Bonnet D, Dick JE. Purification of primitive human hematopoietic cells capable of repopulating immune-deficient mice. Proc Natl Acad Sci USA 1997; 94:5320-5.

19 Bhatia M, Bonnet D, Murdoch B, Gan OI, Dick JE. A newly discovered class of human hematopoietic cells with SCID-repopulating activity. Nat Med 1998; 4:1038-45.

20 Zanjani ED, Almeida-Porada G, Livingston AG, Flake AW, Ogawa M. Human bone marrow CD34- cells engraft in vivo and undergo multilineage expression that includes giving rise to CD34+ cells. Exp Hematol 1998; 26:353-60.

21 Gallacher L, Murdoch B, Wu DM, et al. Isolation and characterization of human CD34(-)Lin(-) and CD34(+)Lin(-) hematopoietic stem cells using cell surface markers AC133 and CD7. Blood 2000; 95:2813-20.

22 Goodell MA, Brose K, Paradis G, Conner AS, Mulligan RC. Isolation and functional properties of murine hematopoietic stem cells that are replicating in vivo. J Exp Med 1996; 183:1797-806.

23 Storms RW, Goodell MA, Fisher A, Mulligan RC, Smith C. Hoechst dye efflux reveals a novel CD7(+)CD34(-) lymphoid progenitor in human umbilical cord blood. Blood 2000; 96:2125-33.

24 Spangrude GJ, Heimfeld S, Weissman IL. Purification and characterization of mouse hematopoietic stem cells. Science 1988; 241:58-62.

25 Weston AD, Rosen V, Chandraratna RA, Underhill TM. Regulation of skeletal progenitor differentiation by the BMP and retinoid signaling pathways. J Cell Biol 2000; 148:679-90.

26 Lev R, Spicer SS. Specific staining of sulphate groups with alcian blue at low pH. J Histochem Cytochem 1964; 12:309.

27 Cash DE, Bock CB, Schughart K, Linney E, Underhill TM. Retinoic acid receptor alpha function in vertebrate limb skeletogenesis: a modulator of chondrogenesis. J Cell Biol 1997; 136: 445-57.

28 Thomas ML, Lefrancois L. Differential expression of the leucocyte-common antigen family. Immunol Today 1988; 9:320-6.

29 Kurtin PJ, Pinkus GS. Leukocyte common antigen-a diagnostic discriminant between hematopoietic and nonhematopoietic neoplasms in paraffin sections using monoclonal antibodies: correlation with immunologic studies and ultrastructural localization. Hum Pathol 1985; 16:353-65.

30 Miraglia S, Godfrey W, Yin AH, et al. A novel five-transmembrane hematopoietic stem cell antigen: isolation, characterization, and molecular cloning. Blood 1997; 90:5013-21.
31 Yin AH, Miraglia S, Zanjani ED, et al. AC133, a novel marker for human hematopoietic stem and progenitor cells. Blood 1997; 90: 5002-12.

32 Ede D. Cellular condensations and chondrogenesis. In Cartilage: Development, Differentiation and Growth 1983; Vol. 2:143-85.

33 Pizette S, Niswander L. BMPs are required at two steps of limb chondrogenesis: Formation of prechondrogenic condensations and their differentiation into chondrocytes. Dev Biol 2000; 219: 237-49.

34 Hall BK, Miyake T. The membranous skeleton: The role of cell condensations in vertebrate skeletogenesis. Anat Embryol 1992; 186: 107-24.

35 Horan PK, Slezak SE. Stable cell membrane labelling. Nature 1989; 340:167-8.

36 Lansdorp PM. In vitro properties of purified human stem cell candidates. J Hematother 1993; 2:329-32.

37 Tsirigotis M, Thurig S, Dube M, et al. Analysis of ubiquitination in vivo using a transgenic mouse model. Biotechniques 2001; 31: 120-6, 8, 30 .

38 Barksi G, Sorieul S, Cornefert. "Hybrid" Type cells in combined cultures of two different mammalian Cell strains. J Natl Cancer Inst 1961; 26:1269-91.

39 Sorieul S, Ephrussi B. Karyological demonstration of hybridization of mammalian cell in vitro. Nature 1961; 190:653-4.

40 Ying QL, Nichols J, Evans EP, Smith AG. Changing potency by spontaneous fusion. Nature 2002; 416:545-8.

41 Terada N, Hamazaki T, Oka M, et al. Bone marrow cells adopt the phenotype of other cells by spontaneous cell fusion. Nature 2002; 416:542-5.

42 de Crombrugghe B, Lefebvre V, Behringer RB, et al. Transcriptional mechanisms of chondrocyte differentiation. Matrix Biol 2000; 19:389-94.

43 Chen P, Carrington JL, Hammonds RG, Reddi AH. Stimulation of chondrogenesis in limb bud mesoderm cells by recombinant human bone morphogenetic protein 2B (BMP-2B) and modulation by transforming growth factor beta 1 and beta 2 . Exp Cell Res 1991; 195:509-15.

44 Cheah KS, Lau ET, Au PK, Tam PP. Expression of the mouse alpha 1(II) collagen gene is not restricted to cartilage during development. Development 1991; 111:945-53.

45 Bi W, Deng JM, Zhang Z, Behringer RR, Crombrugghe B de. Sox 9 is required for cartilage formation. Nat Genet 1999; 22:85-9.

46 Eaves CJ, Sutherland HJ, Udomsakdi C, et al. The human hematopoietic stem cell in vitro and in vivo. Blood Cells 1992; 18: 301-7.

47 Craig W, Kay R, Cutler RB, Lansdorp PM. Expression of Thy1 on human hematopoietic progenitor cells. J Exp Med 1993; 177:1331-42.

48 Ash RC, Detrick DA, Zanjani ED. Studies of human pluri-potential hemopoietic stem cells (CFU-GEMM) in vitro. Blood 1981; 58:309-16.

49 Lasky LC, Ash RC, Kersey JH, Zanjani ED, McCullough J. Collection of pluripotential hematopoietic stem cells by cytapheresis. Blood 1982; 59:822-7.

50 Owen ME, Cave J, Joyner CJ. Clonal analysis in vitro of osteogenic differentiation of marrow CFU-F. J Cell Sci 1987; 87:731-8.

51 Waller EK, Olweus J, Lund-Johansen F, et al. The "common stem cell" hypothesis reevaluated: human fetal bone marrow contains separate populations of hematopoietic and stromal 
progenitors. Blood 1995; 85:2422-35.

52 Link H, Arseniev L, Bahre O, et al. Transplantation of allogeneic CD34 ${ }^{+}$blood cells. Blood 1996; 87:4903-9.

53 Thomson JA, Itskovitz-Eldor J, Shapiro SS, et al. Embryonic stem cell lines derived from human blastocysts. Science 1998; 282:1145-7.

54 Lebkowski JS, Gold J, Xu C, et al. Human embryonic stem cells: culture, differentiation, and genetic modification for regenerative medicine applications. Cancer J 2001; 7 Suppl 2:S83-93.

55 Wiles MV, Keller G. Multiple hematopoietic lineages develop from embryonic stem (ES) cells in culture. Development 1991; 111:259-67.

56 Ahrens M, Ankenbauer T, Schroder D, et al. Expression of human bone morphogenetic proteins- 2 or -4 in murine mesenchymal progenitor $\mathrm{C} 3 \mathrm{H} 10 \mathrm{~T} 1 / 2$ cells induces differentiation into distinct mesenchymal cell lineages. DNA Cell Biol 1993; 12:871-80.

57 Tajbakhsh S, Cossu G. Establishing myogenic identity during somitogenesis. Curr Opin Genet Dev 1997; 7:634-41.

58 Schultheiss TM, Burch JB, Lassar AB. A role for bone morphogenetic proteins in the induction of cardiac myogenesis. Genes Dev 1997; 11:451-62.

59 Maeno M, Mead PE, Kelley C, et al. The role of BMP-4 and GATA-2 in the induction and differentiation of hematopoietic mesoderm in Xenopus laevis. Blood 1996; 88:1965-72.

60 Bhatia $\mathrm{M}$, Bonnet $\mathrm{D}, \mathrm{Wu} \mathrm{D}$, et al. Bone morphogenetic proteins regulate the developmental program of human hematopoietic stem cells. J Exp Med 1999; 189:1139-48.

61 Hogan BL. Bone morphogenetic proteins in development. Curr Opin Genet Dev 1996; 6:432-8.

62 Wozney JM, Rosen V. Bone morphogenetic protein and bone morphogenetic protein gene family in bone formation and repair. Clin Orthop 1998:26-37.

63 Govender S, Csimma C, Genant HK, et al. Recombinant human bone morphogenetic protein-2 for treatment of open tibial fractures: a prospective, controlled, randomized study of four hundred and fifty patients. J Bone Joint Surg Am 2002; 84-A: 2123-34.

64 Schwartz RE, Reyes M, Koodie L, et al. Multipotent adult progenitor cells from bone marrow differentiate into functional hepatocyte-like cells. J Clin Invest 2002; 109:1291-302.

65 Majumdar MK, Thiede MA, Haynesworth SE, Bruder SP, Gerson SL. Human marrow-derived medenchymal stem cells (MSCs) express hematopoietic cytokines and support long-term hematopoiesis when differentiated towards stromal and osteogenic lineages,. J Hematother Stem Cell Res 2000; 9:841-8.

66 Jiang Y, Jahagirdar BN, Reinhardt L, et al. Pluripotency of mesenchymal stem cells deroved from adult marrow. Nature 2002; 418:41-9.

67 Clarke DL, Johansson CB, Wilbertz J, et al. Generalized potential of adult neural stem cells. Science 2000; 288:1660-3. 